\title{
DUAS DÉCADAS DE RELEVANTES MUDANÇAS NA PROTEÇÃO DADA À MULHER PELO DIREITO PENAL BRASILEIRO
}

\author{
TWO DECADES OF RELEVANT CHANGES IN THE PROTECTION GIVEN TO WOMEN UNDER
}

\author{
THE BRAZILIAN CRIMINAL LAW
}

\section{Mariângela Gama de Magalhães Gomes*}

\begin{abstract}
Resumo:
O artigo traz uma reflexão sobre as alterações ocorridas no ordenamento jurídicopenal brasileiro nas duas primeiras décadas do século 21 , especialmente quanto à proteção dispensada às mulheres. Busca-se evidenciar que num período de apenas 20 anos foram efetivadas mudanças com grande impacto na forma como a mulher é vista, como sua sexualidade é tratada e como a violência contra ela passou a receber atenção diferenciada pelo direito penal. Para compreender o significado simbólico dos dispositivos vigentes no final do século 20, é feita uma breve análise dos valores que nortearam a elaboração do código penal de 1940 e que continuavam orientando a sua interpretação na década de 1990; a partir daí, é dado destaque à eliminação de características da lei penal que não faziam sentido no contexto social, tais como a superação da proteção dos "costumes" pela dignidade sexual, a descriminalização do rapto e da sedução, a eliminação de tratamento diferenciado aos crimes que ofendem homens e mulheres, a supressão da figura da "mulher honesta" e o fim do casamento da ofendida como causa de extinção da punibilidade do agressor. Também no sentido de atualização da matéria, é analisada a incriminação do assédio sexual, a Lei "Maria da Penha" e a prevenção e repressão da violência doméstica, a autorização do aborto de feto anencéfalo, a criação da figura do feminicídio e novas incriminações como a importunação sexual e a pornografia de vingança. Para um tema muito vinculado a valores solidamente arraigados na sociedade, as mudanças operadas em duas décadas caracterizam avanço inédito na proteção das mulheres.

Palavras-chave: Código penal. Proteção das mulheres. Gênero. Crimes sexuais. Violência doméstica. Lei Maria da Penha. Feminicídio. Assédio sexual. Aborto. Estupro.
\end{abstract}

\begin{abstract}
:
The paper reflects on the changes that occurred in the Brazilian criminal system in the first two decades of the 21 st century, especially regarding the protection provided to women. It seeks to show that in a period of just 20 years, changes were made with great impact on the way women are seen, how their sexuality is treated and how violence against them started to receive differentiated attention under criminal law. To understand the symbolic meaning of the provisions in force at the end of the 20th century, a brief analysis of the values that guided the elaboration of the 1940 Criminal Code and that continued to guide its interpretation in the 1990s is made; from then on, the emphasis is placed on the elimination of characteristics of the
\end{abstract}

\footnotetext{
* Bacharela da Turma 167 da Faculdade de Direito da USP, Mestre, Doutora e Livre-Docente em Direito Penal pela USP e Professora de Direito Penal na mesma instituição.E-mail: mariangela@usp.br.
} 
criminal law that did not make sense in the social context, such as the overcoming the protection of "customs" by sexual dignity, the decriminalization of kidnapping for sexual purposes and seduction, the elimination of different treatment to crimes that offend men and women, the suppression of the figure of the "honest woman" and the end of the victim's marriage as the cause of extinction of criminal liability. of the aggressor. Also in the sense of updating the matter, the incrimination of sexual harassment, the "Maria da Penha" Law and the prevention and repression of domestic violence, the authorization of abortion of anencephalic fetus, the creation of the figure of feminicide and new incriminations such as sexual nuisance and revenge porn. For a theme that is closely linked to values that are firmly rooted in society, the changes made in two decades characterize an unprecedented advance in protecting women.

Keywords: Criminal Code. Protection of women. Gender. Sexual crimes. Domestic violence. Maria da Penha Law. Femicide. Sexual harassment. Abortion. Rape.

\section{Introdução}

Em novembro de 2018, como parte das comemorações de 20 anos de formatura da turma 167 da Faculdade de Direito da USP, foi realizado o Seminário "SANFRAN + 20", onde foi proposta uma reflexão sobre as mudanças ocorridas no ordenamento jurídico brasileiro após a formatura da turma. Naquela oportunidade, um dos temas apresentados foi o tratamento dado pelo direito penal brasileiro à mulher, especialmente no que diz respeito às violências relacionadas aos papéis de gênero dedicados a homens e mulheres na sociedade.

É com o objetivo de registrar esse evento e, também, de aprofundar esse tema tão caro e importante nos dias atuais, que se propõe esse artigo. Buscar-se-á, assim, identificar os valores que ainda norteavam esse assunto no final do século 20, que impactavam na interpretação e aplicação do direito e, consequentemente, muito revelam sobre nossa sociedade àquela altura; ao mesmo tempo, serão apontadas algumas importantes alterações legislativas e jurisprudenciais que, num lapso temporal de apenas 20 anos, trouxeram ao nosso direito uma significativa mudança de perspectiva.

O interesse dessa análise relaciona-se com a íntima relação entre os valores socioculturais que permeiam o desenvolvimento das relações humanas e as normas jurídicas dispostas a disciplinar os atos da vida social, o que torna evidente a grande influência que os costumes e os valores relacionados à moral sexual sempre tiveram na estruturação do ordenamento jurídico-penal, especialmente no tocante às condutas envolvendo práticas sexuais. Nesse sentido, no limiar do século 21 destacava-se o quanto o direito penal brasileiro ainda se prendia à lógica patriarcal que norteou as relações sociais no país desde sua colonização, mesmo constatando-se a inadequação de muitas das normas que continuavam sendo aplicadas e orientando comportamentos. Da mesma 
forma, deve ser também motivo de acurada análise a profunda alteração realizada, pelo direito penal positivado, nas diretrizes axiológicas a guiar a matéria, em período de tempo relativamente muito curto para o volume de alterações levadas a cabo.

Assim, será apresentada, inicialmente, uma fotografia dos valores que nortearam a codificação penal de 1940 e que continuavam orientando o tema na década de 1990 e início dos anos 2000, tanto na academia como na prática forense; em seguida, serão comentadas algumas das significativas alterações legislativas que excluíram do sistema penal visões acerca dos papéis de gênero que já não mais faziam sentido às vésperas do século 21; por fim, será feita referência a mudanças mais recentes, fortemente influenciadas pela militância feminina que busca igualdade de tratamento e oportunidades para homens e mulheres - o que inclui, evidentemente, a prevenção e repressão das diversas violências de gênero enraizadas na sociedade - e que apontam para um novo patamar de proteção penal às mulheres.

\section{A mulher no CP de 1940}

Para melhor compreender o tratamento dispensado à mulher pelo código penal de 1940, importante ponto de partida é o conhecimento da forma como as leis anteriores dispuseram sobre a matéria, uma vez que as regras ali definidas refletem valores sociais que foram sendo sedimentados ao longo de toda a história do direito penal brasileiro - e que deles não se afastaram.

De início, podem ser destacadas algumas das condutas incriminadas pelo código penal de 1940 e que continuavam em vigor em 1998: "seduzir mulher virgem, menor de dezoito anos e maior de quatorze, e ter com ela conjunção carnal, aproveitandose de sua inexperiência ou justificável confiança"; "raptar mulher honesta, mediante violência, grave ameaça ou fraude, para fim libidinoso"; "ter conjunção carnal com mulher honesta, mediante fraude"; "induzir mulher honesta, mediante fraude, a praticar ou permitir que com ela se pratique ato libidinoso diverso da conjunção carnal"; "cometer adultério". É também ilustrativo dos valores norteadores do ordenamento jurídico daquela época o fato de que, para o crime de rapto, por exemplo, encontrava-se a previsão de diminuição da pena se fosse para fim de casamento ou se o agente, sem ter praticado com a vítima qualquer ato libidinoso, a restituísse à liberdade ou a colocasse em lugar seguro, à disposição da família; de maneira mais ampla, previa-se a extinção da punibilidade para autores de crimes sem violência real, como estupro, atentado violento ao pudor, sedução e rapto, entre outros, que viessem a se casar com a respectiva vítima.

Uma vez que os valores veiculados por disposições penais como as suprarreferidas não foram inseridos abruptamente no ordenamento jurídico, sua intrínseca relação com a moral da época pode ser melhor evidenciada a partir da compreensão 
dos papéis tradicionalmente atribuídos às mulheres até então. Para essa finalidade, imprescindível também identificar o valor atribuído ao casamento entre homem e mulher, que norteava a própria existência feminina na sociedade.

Nesse sentido, importante recordar o papel passivo tradicionalmente atribuído à mulher na sociedade patriarcal desde o final da Idade Média, já que estava sujeita, sempre, ao poder de um homem: da submissão ao pai passava, ainda adolescente, às mãos do marido. $\mathrm{O}$ casamento apresentava-se, para a mulher, como condição de respeitabilidade e segurança, sendo a única instituição que lhe permitia realizar-se como ser social. Sem um homem a seu lado que lhe proporcionasse exercer o papel de "santa esposa e mãe", a mulher - naturalmente frágil - praticamente inexistia (DEL PRIORE, 2013).

A família constituía, portanto, um universo totalitário, com apenas um sujeito, um interesse e um direito, sem lugar para discussões, mas apenas para juízos arbitrários de oportunidade, a critério do bonus pater familias. Entre os atos de natureza pessoal e patrimonial que bem expressavam a ideia de que "o marido é a cabeça da mulher" estavam, por exemplo, a faculdade generalizada que ele tinha de dirigi-la, de defendê-la e sustentá-la, assim como de corrigi-la moderadamente - o que frequentemente se transformava em sevícias (HESPANHA, 1993).

Vê-se, assim, que embora seja verdade que as relações entre os cônjuges pressupunham algumas situações de igualdade, tais como a promessa recíproca de ajuda, de fidelidade e de vida em comum, a nota características de tais convivências era a desigualdade. ${ }^{1}$

Por outro lado, importante destacar que a procriação se apresentava como a principal finalidade do casamento, de modo que somente era considerada "natural" a sexualidade que visasse a esse fim. Isso faz com que as práticas sexuais voltadas apenas ao prazer fossem tidas como contra natura, assim como aquelas diferentes do "coito natural e honesto" (HESPANHA, 1993).

Nesse contexto sociocultural, resta fácil identificar o lugar ocupado pelas mulheres na época da elaboração e entrada em vigor do código penal. Veja-se, a título de exemplo, o Decreto de abril de 1941 assinado por Getúlio Vargas orientando a formação de mulheres "afeiçoadas ao casamento, desejosas da maternidade, competentes para a

Exemplo dado por Hespanha (1993) diz respeito ao tratamento dado ao adultério, já que, embora fosse igualmente censurável do ponto de vista da moral abstrata, para a moral positiva o adultério da mulher tinha o peso de fazer cair o ultraje sobre os filhos e obscurecer a paternidade, além de causar aos maridos uma dor maior do que a da morte dos filhos. Na mesma toada, Del Priore (2013) destaca o consenso que havia no sentido de que o homem, por sua vida mais livre, por ficar sempre fora de casa e devido à sua educação, é mais facilmente tentado a cometer uma infidelidade conjugal, sem que isso signifique uma nódoa em seu caráter; enquanto o mundo olha com indulgência a traição do homem, não desculpa aquela da mulher. 
criação dos filhos e capazes na administração da casa". Já as revistas voltadas ao público feminino, com grande penetração social, contribuíam para a mesma compreensão da realidade; o "Jornal das Moças", em edição de outubro de 1955, por sua vez, trazia o seguinte aconselhamento: "A mulher tem uma missão a cumprir no mundo: a de completar o homem. Ele é o empreendedor, o forte, o imaginoso. Mas precisa de uma fonte de energia [...] a mulher o inspira, o anima, o conforta [...] a arte de ser mulher exige muita perspicácia, muita bondade. Um permanente sentido de prontidão e alerta para satisfazer às necessidades dos entes queridos" (DEL PRIORE, 2013).

\section{Da tutela dos costumes à proteção da dignidade sexual}

A primeira constatação que vem à tona quando são comparados os crimes previstos no código penal contra o exercício da sexualidade pela mulher é aquela referente à nomenclatura do Título VI da parte especial, o que significa dizer que se trata do bem jurídico oficialmente protegido pelas normas.

Embora seja verdade que o bem jurídico preexiste à atuação do legislador, na medida em que é um valor importante para dada sociedade e não criado artificialmente por quem tem a tarefa de criar os tipos incriminadores, é importante destacar que a classificação legislativa dada a referido valor tem um papel relevante não apenas para revelar como ele é compreendido, mas também para orientar a interpretação das normas e a elaboração dogmática de institutos jurídicos. Nesse sentido, o bem jurídico é um dado concretamente perceptível, ao menos conceitualmente, e seu sentido apreendido na vida da comunidade, de acordo com sua realidade econômica e social (FLORA, 1998).

Assim, desde logo, a comparação entre os bens jurídicos tutelados pelo código penal em 1998 e 2018 mostra uma significativa mudança na concepção acerca de qual é o valor que justifica a punição de crimes caracterizados pela violação sexual das mulheres.

De um lado, permanecia vigente, no final do século 20, a mesma ideia que havia orientado a elaboração do código penal em 1940, e que justificava a proibição do estupro ou da sedução, por exemplo, no fato de tais condutas ofenderem os costumes; nos termos do próprio legislador, expressos no item 71 da Exposição de Motivos da parte especial do CP, "o direito penal não pode abdicar de sua função ética, para acomodar-se ao afrouxamento dos costumes". De outro lado, por sua vez, no final da segunda década do século 21, o ordenamento jurídico brasileiro considera que a legitimidade para a criminalização de certos comportamentos atentatórios à sexualidade das mulheres está no fato de haver, nesses casos, ofensa à dignidade sexual.

Embora, em 1998, já se passassem quase sessenta anos desde a elaboração do código penal, o fato de termos crimes que oficialmente atentavam contra os costumes 
significa que ainda se fazia presente, pelo menos em alguma medida, o mesmo pensamento que orientou a classificação dos crimes descritos no Título VI da parte especial. A esse respeito, são ilustrativas as palavras de Magalhães Noronha:

A vida social necessita da moralidade pública, conjunto de normas que ditam o comportamento a ser observado nos domínios da sexualidade. Primeiramente, surgem como princípios de ordem ética, para depois se tornarem jurídicos. Impedem aquelas manifestações que constituem desvio ou aberração da função sexual normal, quer sob o ponto de vista biológico, quer sob o social. (NORONHA, 1969).

Nelson Hungria e Romão Lacerda, a seu turno, explicavam que

o vocábulo 'costumes' é aí empregado para significar (sentido restritivo) os hábitos da vida sexual aprovados pela moral prática, ou, o que vale o mesmo, a conduta sexual adaptada à conveniência e disciplina sociais. $\mathrm{O}$ que a lei penal se propõe tutelar, in subjecta materia, é o interesse jurídico concernente à preservação do mínimo ético reclamado pela experiência social em torno dos fatos sexuais. (HUNGRIA; LACERDA, 1959).

A partir dessas considerações, não é difícil apreender o distanciamento entre os valores que nortearam a tipificação das condutas descritas no Título VI da parte especial do código penal de 1940 e os princípios basilares do Estado brasileiro fundado pela Constituição Federal de 1988.

É que, no Estado Democrático de Direito, o papel central que o ser humano deve exercer no ordenamento jurídico impõe que, no direito penal, ele seja tomado como um valor ético em si, e não instrumento para outra finalidade qualquer; a legitimidade da intervenção penal requer a existência de uma ofensa ou agressão a um bem essencial ao pleno desenvolvimento da sociedade. Com o jus puniendi estruturado a partir da centralidade do ser humano, Ferrando Mantovani (1997) observa ser incabível compreender o direito penal como uma forma de limitação da liberdade, mas - ao contrário - como instrumento de liberdade; da mesma forma, Luiz Régis Prado (1996) destaca que a lei penal não atua como limite da liberdade pessoal, mas como seu garante.

$\mathrm{Na}$ análise do bem jurídico protegido em crimes caracterizados pela prática sexual mediante violência ou fraude, por exemplo, cabe lembrar, ainda, a advertência de Nilo Batista (1999) quando aponta, entre as funções da exigência de ofensividade das condutas a serem criminalizadas, a proibição da incriminação de condutas desviadas de eventual padrão de práticas ou hábitos da maioria da coletividade quando não atinjam qualquer bem jurídico de outros indivíduos; trata-se de privilegiar o "direito à diferença". Assim, pode-se afirmar como necessária e correta a alteração realizada em 2009, pela Lei n. 12.015, que substituiu o bem jurídico costumes pela dignidade sexual, 
que passou a ser a referência axiológica para a interpretação e compreensão das infrações contidas no Título VI da parte especial do código penal brasileiro. ${ }^{2}$

Essa modificação realizada pelo legislador encontra-se, portanto, adequada aos novos parâmetros constitucionais que norteiam a sociedade brasileira, marcada pelo pluralismo e pelo apreço à liberdade individual. Como lembra Tadeu Dix Silva (2006), nesse campo, deve prevalecer a convivência de diferentes padrões de preferência sexual, tanto no que diz respeito às formas como às práticas às quais cada um escolhe se dedicar. A garantia de uma vivência plural, em sua plenitude, deve impedir qualquer interferência estatal - especialmente com o uso do direito penal - que se baseie em referências subjetivas como os costumes, a moralidade pública ou a moral sexual.

\section{A descriminalização do rapto e da sedução}

Assim como, em 1998, fazia-se necessária a atualização do bem jurídico que justificava a criminalização de determinadas condutas atentatórias à liberdade sexual das pessoas, o mesmo pode ser dito em relação a pelo menos dois dos crimes ali previstos. Foi somente em 2005, no entanto, por meio da já referida Lei n. 12.015, que as figuras da sedução e do rapto foram extirpadas do ordenamento jurídico brasileiro. Embora fosse evidente que tais incriminações não mais se justificavam depois de sessenta e cinco anos da vigência do código penal, até aquele ano tais comportamentos poderiam ensejar a intervenção penal do Estado para fazer incidir a mais drástica sanção prevista no ordenamento jurídico brasileiro.

Com relação ao crime de sedução, o art. 217 do código penal previa pena de reclusão de dois a quatro anos a quem seduzisse mulher virgem, menor de dezoito anos e maior de quatorze, e tivesse com ela conjunção carnal, aproveitando-se de sua inexperiência ou justificável confiança. Já o rapto estava disposto no art. 219 do código penal e previa pena igual à da sedução a quem raptasse mulher honesta, mediante violência, grave ameaça ou fraude, para fim libidinoso. Quanto ao rapto, ainda, punia-se de forma mais branda se o crime se desse com o consentimento da raptada, se o rapto fosse para fim de casamento, se não fosse praticado ato libidinoso com a vítima e ela fosse restituída à liberdade ou colocada em lugar seguro, à disposição da família. ${ }^{3}$

2 Registre-se, aqui, a inexistência de unanimidade quanto à escolha do bem jurídico dignidade sexual como valor de referência para os crimes ali descritos. É que há autores, tais como Tadeu Dix Silva, que ponderam haver nesse termo um certo caráter moralista, como se dissesse que há atos sexuais dignos e outros indignos, ou seja, como se a tutela penal não abarcasse condutas sexuais consideradas indecorosas ou impudicas, num retorno à moral e ao pudor como critérios para a criação de tipos penais - o que é incompatível com a livre determinação sexual (SILVA, 2006).

3 Art. 219. Raptar mulher honesta, mediante violência, grave ameaça ou fraude, para fim libidinoso: Pena - reclusão, de dois a quatro anos. Art. 220. Se a raptada é maior de catorze anos e menor de vinte e um, 
A clara dissonância entre a manutenção da criminalização dessas condutas e a sociedade brasileira no início do século 21 pode ser verificada no anacronismo da Exposição de Motivos do código penal que, quanto ao rapto, expressava no item 73 a prevalência dos valores da organização familiar sobre a liberdade individual. ${ }^{4} \mathrm{O}$ item 71 , a seu turno, embora tivesse por objetivo específico justificar a incriminação da sedução, é exemplar não só da forma preconceituosa como as mulheres eram vistas e tratadas, mas evidencia um pensamento em relação ao qual até hoje a sociedade brasileira ainda não conseguiu desvencilhar-se. Consta em tal documento:

Em abono do critério do projeto, acresce que, hoje em dia, dados os nossos costumes e formas de vida, não são raros os casos em que a mulher não é a única vítima da sedução.

Já foi dito, com acerto, que 'nos crimes sexuais, nunca o homem é tão algoz que não possa ser, também, um pouco vítima, e a mulher nem sempre é a maior e a única vítima dos seus pretendidos infortúnios sexuais' (Filipo Manci, Delitti sessuali).

A doutrina nacional, no mesmo sentido, apresentava explicações como a seguinte, do final da década de 1960:

Capitulando o delito de sedução, protege a lei a virgindade da mulher menor de dezoito anos. Foi o Código ao encontro da moral e da tradição do povo, a quem ainda repugna facilitar-se à mulher o congresso carnal, remetendo-a depois ao casamento, tal como ele existe entre nós, conhecedora perfeita dos prazeres da carne, altamente versada no emprego dos meios anticoncepcionais, experimentada das práticas abortivas, quando não mãe de filho de... pai desconhecido, o que, por certo, comprometeria a constituição da família desde o nascedouro. (NORONHA, 1969).

5. O tratamento igualitário a homens e mulheres na disciplina dos crimes sexuais

Outra importante alteração legislativa nesse período de 20 anos, que impactou na descrição típica de alguns comportamentos considerados reprováveis do ponto de vista da liberdade sexual, se deu com a Lei n. 12.015/09. Por meio desse

e o rapto se dá com seu consentimento: Pena - detenção, de um a três anos. Art. 221. É diminuída de um terço a pena, se o rapto é para fim de casamento, e de metade, se o agente, sem ter praticado com a vítima qualquer ato libidinoso, a restitui à liberdade ou a coloca em lugar seguro, à disposição da família.

$4 \quad$ "No rapto, se violento, fraudulento ou consensual, o fim do agente é a posse da vítima para fim sexual ou libidinoso. Trata-se de um crime dirigido contra o interesse da organização ético-social da família - interesse que sobreleva o da liberdade pessoal. Seu justo lugar, portanto, é entre os crimes contra os costumes". 
diploma legal foi superada a diferenciação típica entre violações sexuais caracterizadas pela conjunção carnal - e, portanto, que só podiam ser praticadas contra mulheres - e aquelas nas quais o ato sexual é diverso da conjunção carnal.

A diferença entre os crimes de estupro e de atentado violento ao pudor, portanto, foi suprimida, e todos os atos libidinosos praticados mediante violência ou grave ameaça passaram a ser abarcados pela figura do estupro, descrita no art. 213 do CP. Embora a Lei dos Crimes Hediondos já tivesse, em 1990, equiparado as penas das duas infrações, a permanência de dois delitos distintos que previam punições separadas à violência sexual a depender da caracterização ou não da conjunção carnal podia indicar a não superação de diferentes valorações às diferentes práticas sexuais.

A par dessa necessária equiparação entre comportamentos que violam de maneira semelhante a liberdade sexual de homens e mulheres, é importante destacar que a expressão "ato libidinoso" é demasiadamente ampla, podendo nela serem incluídos diversos comportamentos que traduzem diversas gravidades. Ao mesmo tempo em que contempla a relação sexual anal ou oral, também pode abarcar a simples apalpação, toques e manobras nas pernas, coxas e seios, assim como nos órgãos genitais, a masturbação e outros comportamentos do gênero (FRANCO; SILVA, 2007). Na jurisprudência, são fartos os exemplos que demonstram a larga abrangência do tipo, que, além das hipóteses já mencionadas, se perfaz, entre outros, com o beijo lascivo, o abraço ou mesmo a contemplação lasciva da vítima (DELMANTO; DELMANTO; DELMANTO JÚNIOR; DELMANTO, 2000). Constata-se, daí, a convivência da ideia de pertinência da aglutinação de diferentes violências sexuais sob o mesmo tipo incriminador com a inevitável crítica quanto ao exagero punitivo a outros comportamentos evidentemente menos lesivos ao mesmo bem jurídico. Esse problema só viria a ser de fato enfrentado anos depois com a criação da figura do crime de importunação sexual, pela Lei n. 13.718/18, conforme será adiante analisado.

$\mathrm{Na}$ mesma toada, foi suprimida a diferenciação entre os crimes de posse sexual mediante fraude (art. 215 do CP) e de atentado ao pudor mediante fraude (art. 216 do CP). Ambas as infrações tinham como sujeito passivo apenas a mulher e caracterizavam-se pelo uso da fraude para levá-la a consentir com a relação sexual, diferenciando-se quanto ao tipo de ato sexual praticado: no primeiro caso, proibia-se a conjunção carnal, ao passo que, no segundo, o ato libidinoso diverso da conjunção carnal. Um exemplo exaustivamente usado para ilustrar tais crimes é, também, bastante útil para ver como o direito penal considerava as mulheres: trata-se do sujeito que, na obscuridade da alcova, insinua-se no leito de uma mulher, fazendo-se passar por seu marido ou amante (HUNGRIA; LACERDA, 1959). Prova de que a jurisprudência não enxergava a mulher de maneira diferente é a decisão em que a posse sexual fraudulenta é considerada caracterizada quando o agente aproveita-se "de estado de semi-sonolência de uma mulher, 
que, pelo hábito de relações sexuais com o marido ou amante, toma a nuvem por Juno e não se alarma à introductio penis" (RJTJSP 47/374).

No que tange aos tipos penais dos arts. 215 e 216 do CP, importante pontuar que, antes da supressão das duas infrações para o surgimento do crime único de violação sexual mediante fraude - que contempla qualquer ato libidinoso e, consequentemente, qualquer sujeito passivo -, a Lei n. 11.106/05 já havia imposto significativas alterações. Uma delas diz respeito à modificação do art. 216 do $\mathrm{CP}$ a fim de proteger não apenas as mulheres, mas todas aquelas pessoas que, mediante fraude, praticassem ou fossem obrigadas a submeter-se à prática de ato libidinoso diverso da conjunção carnal.

6. A eliminação da figura da "mulher honesta" no direito penal

Entre tantas modificações, uma que teve grande simbolismo nesse período foi a eliminação da expressão "mulher honesta", referente ao sujeito passivo dos dois tipos penais referidos no tópico anterior.

A categorização da mulher, enquanto vítima de crimes, foi uma constante no direito penal brasileiro, especialmente em casos de violações sexuais, nos quais o status da mulher na sociedade tinha o condão de classificar a gravidade da conduta praticada. Assim, como lembra Marilia Montenegro (2015), na condição de sujeito passivo dos crimes sexuais, a mulher já foi categorizada como "virgem", "honesta", "prostituta", "pública". A depender da categoria na qual a mulher se encaixasse, o comportamento a ela direcionado poderia adquirir ou não relevância criminal, assim como o grau da sua reprovação poderia oscilar.

Em 1998, portanto, ainda estava presente no direito penal positivado o último resquício de uma tradição que até então sempre fizera parte da legislação brasileira, desde as Ordenações Filipinas. A título de exemplo, referida codificação continha, em seu Título XVI, a infração intitulada "Do que dorme com uma mulher, que anda no Paço, ou entra em casa de alguma pessoa para dormir com mulher virgem, ou viúva honesta, ou escrava branca de guarda", deixando claro a quais mulheres se referia; no Código Criminal de 1830, a figura do estupro dizia respeito exclusivamente ao defloramento de mulher virgem (art. 219), ao passo que a sedução consistia em "seduzir mulher honesta, menor de dezessete anos..." (art. 224); o Código Penal de 1890, por sua vez, exigia que, para a caracterização do estupro, a mulher não precisava mais ser virgem, mas deveria ser honesta (art. 268).

Referida honestidade da mulher continha em sua essência o mesmo juízo moral que orientou a moral sexual da sociedade brasileira durante toda a sua existência. Isso fica claro nas lições doutrinárias referentes à matéria. Entre os autores mais antigos, podem ser destacados Nelson Hungria, Romão Lacerda e Magalhães Noronha: 
A vítima deve ser mulher honesta, e como tal se entende, não somente aquela cuja conduta, sob o ponto de vista da moral sexual, é irrepreensível, senão também aquela que ainda não rompeu com o minimum de decência exigido pelos bons costumes. Só deixa de ser mulher honesta (sob o prisma jurídico-penal) a mulher francamente desregrada, (...) ainda que não tenha descido à condição autêntica de prostituta. Desonesta é a mulher fácil, que se entrega a uns e outros, por interesse ou mera depravação. (HUNGRIA; LACERDA, 1959).

A expressão mulher honesta repudia a que, embora sem ser meretriz, é fácil prodigalizadora de seus favores. Mulher desonesta não é somente a que faz mercancia do corpo. É também a que, por gozo, depravação, espírito de aventura etc., entrega-se a quem a requesta. Não é só o intuito de lucro que infama a posse da fêmea. A conduta da horizontal, muita vez, é digna de comiseração, o que se não dá com a de quem, livre das necessidades, se entrega tão-só pelo gozo, volúpia ou luxúria. (NORONHA, 1969).

Importante destacar, no entanto, que essa interpretação não tinha ficado adstrita aos contemporâneos do código de 1940, uma vez que também autores que escreviam às vésperas do século 21 reproduziam o mesmo entendimento, como se evidenciava nos manuais de direito penal mais lidos nos últimos anos do século 20:

(...) Inclui-se na lei um elemento normativo, que obriga a um juízo de valor, ao se exigir a honestidade da mulher. Honesta é a mulher honrada, decente, de compostura (...). Estão excluídas da proteção, portanto, não só as prostitutas como as promíscuas, francamente desregradas, as mulheres fáceis, de vários leitos (RT 436/342). A razão da exclusão deve-se à maior dificuldade em se iludir a barregã e a mulher depravada, bem como o pouco relevo do coito fraudulento com tais pessoas. (MIRABETE, 1996).

Mulher honesta é aquela que se conduz pelos padrões aceitos pela sociedade onde vive. É a que mantém a conduta regrada, honrada e decente, de acordo com os bons costumes. Não se exige, todavia, um comportamento irrepreensível, mormente dentro dos padrões de liberdade sexual predominantes. Pautando-se a mulher pelo mínimo de decência exigido pelos nossos costumes, será honesta. (JESUS, 1999).

Importante destacar que, até 2005, quando a figura da "mulher honesta" foi definitivamente retirada do ordenamento punitivo, eram comuns as referências doutrinárias que repetiam as mesmas fórmulas definidoras sobre quais mulheres merecem respeito e quais não fazem jus à proteção jurídica do Estado. Embora fosse evidente que, 
àquela altura, referido entendimento já se encontrava descolado da realidade e precisava ser alterado, eram raras as vozes que contestavam a perpetuação da forma discriminatória com a qual a lei penal se referia às mulheres, como se vê na lição transcrita abaixo:

\begin{abstract}
Seria honesta, atualmente, a mulher que tomasse a iniciativa da conquista e investisse sobre os parceiros, exatamente como faz o homem com relação à mulher? Seria honesta a mulher que apreciasse o sexo, exatamente como sempre se incentivou o homem a fazer, trocando de parceiros várias vezes? Se a resposta for afirmativa, fruto natural da liberdade sexual, não há, de fato, razão para a existência do tipo penal do art. 215, que somente poderia ter em vista proteger exceções. De outra parte, se a resposta for negativa está-se diante de um impasse, pois a interpretação valorativa do termo inserido no tipo penal demonstraria seu descompasso com a realidade. (NUCCI, 2003).
\end{abstract}

7. O fim do casamento da ofendida como causa de extinção da punibilidade do agressor

Outro elemento que caracterizava o ordenamento jurídico-penal do final do século 20 era a possibilidade do casamento da vítima como causa extintiva da punibilidade, nos casos de crimes sexuais. Nos termos do inciso VII do art. 107 do CP, a punibilidade extinguia-se "pelo casamento do agente com a vítima, nos crimes contra os costumes, definidos nos Capítulos I, II e III do Título VI da Parte Especial”, ao passo que o inciso VIII previa a extinção da punibilidade "pelo casamento da vítima com terceiro, nos crimes referidos no inciso anterior, se cometidos sem violência real ou grave ameaça e desde que a ofendida não requeira o prosseguimento do inquérito policial ou da ação penal no prazo de 60 (sessenta) dias a contar da celebração".

Ambas as previsões foram revogadas pela Lein. 11.106/05, mas - assim como tantos outros elementos aqui identificados - continham em si um valor muito significativo acerca de como as mulheres eram vistas pela sociedade e, mais especificamente, de como alguns crimes eram interpretados pelo ordenamento jurídico.

Como destaca Marilia Montenegro (2015), referidos dispositivos espelham uma sociedade repressora da sexualidade feminina, o que fica claro pela expectativa de que a mulher deveria se casar virgem. Na hipótese de ela ter mantido relações sexuais antes do casamento e, portanto, ter se inviabilizado para uma futura união, haveria a necessidade de reparação do dano por parte de quem a "violou", casando-se com ela. Outra possibilidade, igualmente prevista entre as causas extintivas da punibilidade, seria o casamento com terceiro, pois nesse caso - segundo a lógica vigente - também perderia sentido uma punição ao violador, tendo em vista que a mulher conseguiu se casar e, 
portanto, não sofreu prejuízo com o crime. Como bem pontuado pela referida autora, exemplos como esses mostram, com facilidade, que grande parte dos crimes contra a liberdade sexual não tinha como escopo a proteção da mulher, mas dos bons costumes, da família e a garantia de um casamento futuro à mulher lesionada.

Cabem aqui também algumas notas sobre o significado dessas causas extintivas da punibilidade que estiveram em vigor até tão pouco tempo atrás.

Assim, desde as Ordenações Filipinas, a legislação penal aplicada no Brasil previa o casamento da mulher vítima de crimes sexuais com seu agressor como causa de não punição, e isso se justificava porque tinha-se a ideia de que tais crimes tinham como sujeito passivo a família, representada pelo seu pai, que seria a pessoa que suportaria o prejuízo de não ter a filha casada. Não é por outro motivo que, além das penas físicas, o condenado tinha que indenizar o pai da moça que, por não ser mais pura, dificilmente conseguiria se casar, conforme estava previsto no TITULO XVI do Livro V das Ordenações Filipinas, nos arts. 219, 222 e 224 do Código Criminal de 1830, e no art. 276 do Código Penal de 1890. Sobre a isenção de pena na hipótese de o agressor casar-se com a vítima, além de estarem previstos nos mesmos dispositivos referidos, nas Ordenações Filipinas havia referência expressa ao fato de que a ofensa era feita à "casa" - ou seja, à família - e não à mulher que sofreu a agressão. ${ }^{5}$

Vê-se, portanto, a partir do ponto de vista histórico, a inadequação de haver no direito brasileiro normas tão representativas de uma mentalidade que há muito tempo já não podia prevalecer - se é que algum dia deveria ter existido. Resta claro, então, como sinal da evolução da sociedade e do lugar nela ocupado pelas mulheres, que não fazia mais sentido a existência das referidas causas excludentes da punibilidade.

\section{A incriminação do assédio sexual}

A partir da virada para o século 21, ganhou corpo um movimento legislativo no sentido de proporcionar mais proteção às mulheres por meio do direito penal. A primeira manifestação nesse sentido se deu pela criminalização do assédio sexual, pela Lei n. 10.224/01. Assim, foi criada a figura do art. 216-A no código penal, proibindo-se "constranger alguém com o intuito de obter vantagem ou favorecimento sexual, prevalecendo-se o agente da sua condição de superior hierárquico ou ascendência inerentes ao exercício de emprego, cargo ou função".

"E se a pessoa, que pelo sobredito modo entrar na dita casa quiser casar com a mulher com quem queria dormir, e ela também quiser, e o morador da casa a quem tal ofensa foi feita, onde entrou, nisso consentir, e lhe perdoar, será relevado de ditas penas". 
Vê-se, com clareza, que se trata de um tipo penal que visa a proteger, além da liberdade sexual, a honra pessoal da pessoa ofendida e o respeito às relações de trabalho (SILVEIRA, 2017). O fato de a incriminação estar inserida no Título do código penal referente aos crimes contra a dignidade sexual permite afirmar que, sem desconsiderar os demais, foi esse bem jurídico o principalmente valorado pelo legislador quando descreveu o comportamento proibido (GOMES, 2014).

Embora o tipo incriminador não seja voltado exclusivamente para a proteção das mulheres - posto que os sujeitos ativo e passivo podem ser pessoas de qualquer gênero -, não é coincidência o fato de o legislador de 1940 não ter vislumbrado a necessidade de se tipificar essa conduta e, no início do século 21 , tal criminalização ter sido considerada necessária.

Ao contrário de 1940, quando as mulheres tinham poucos direitos e eram raras as que estavam no mercado formal de trabalho, o cenário vislumbrado no final do século 20 era bem diferente. Essa constatação permite compreender o surgimento de nova forma pela qual a violência de gênero se tornou presente em nossa sociedade, qual seja, o constrangimento, a importunação ou a intimidação com propostas indevidas, de caráter sexual, dirigidas às mulheres trabalhadoras, feitas por quem representa ameaça à sua manutenção no emprego ou crescimento profissional, dada a superioridade hierárquica ou de função - em geral representada por um homem (CHAKIAN, 2019).

É importante ressaltar que, antes da criação do tipo incriminador do assédio sexual, eventual ameaça ou constrangimento ilegal impostos à funcionária recebiam a censura penal por meio dos crimes previstos nos arts. 146 e 147 do CP, embora não houvesse ali uma reprovação específica voltada a tutelar o homem ou a mulher no ambiente laboral, frente a investidas de cunho sexual. A redação escolhida pelo legislador para a descrição do comportamento proibido, por sua vez, é objeto de severas críticas por parte da doutrina, que não vislumbra contornos precisos que atendam à garantia do princípio da taxatividade penal. Além disso, deve ser feito destaque para a limitação da proteção da mulher somente no contexto das relações de trabalho, uma vez que o tipo penal não abarca expressamente outras formas de subordinação nas quais pode haver aproveitamento da sua situação de vulnerabilidade, como se dá na relação entre professor e aluna ou entre autoridade religiosa e fiel, por exemplo (SILVEIRA, 2017).

9. A Lei Maria da Penha e o início da construção de um sistema integral de proteção à mulher vítima de violência doméstica

Bastante significativa, no ordenamento jurídico brasileiro, foi a aprovação da Lei n. 11.340/06, que trouxe um sistema integrado de proteção à mulher em situação de violência doméstica. É imprescindível relacioná-la com o compromisso internacional 
assumido pelo Brasil com o combate a todas as formas de discriminação contra as mulheres e com a erradicação da violência contra elas, o que está expresso na própria lei, quando é feita menção à CEDAW, de 1979, e à Convenção de Belém do Pará, de 1994. ${ }^{6}$ Para além dessas referências, trata-se também de resposta dada pelo Brasil às recomendações que lhe foram apresentadas pela Comissão Interamericana de Direitos Humanos, no Relatório n. 54/01 do Caso 12.051, referente ao caso Maria da Penha Maia Fernandes - motivo pelo qual a lei veio a ser conhecida como "Lei Maria da Penha".

Para a compreensão do vulto das mudanças que se deram no ordenamento jurídico brasileiro acerca da violência doméstica contra as mulheres nos últimos vinte anos, é importante lembrar que, na década de 1990, a Lei n. 9.099/95 instituiu os Juizados Especiais Criminais e trazido importantes modificações no processo penal atinente às infrações de menor potencial ofensivo, definidas como as contravenções penais e os crimes cujas penas máximas não fossem superior a um ano. Assim, o impacto dessa lei no tratamento penal da violência doméstica foi imediato, especialmente porque a maior parte dos casos desse tipo reportados dizem respeito a lesões corporais leves, cuja pena máxima era, até 2006, um ano de detenção.

Orientado pelos critérios da oralidade, simplicidade, informalidade, economia processual e celeridade, e com vistas à reparação dos danos sofridos pela vítima e à aplicação de pena não privativa de liberdade, o processo penal perante os Juizados Especiais contemplava a possibilidade de um acordo civil entre as partes ou a transação penal com o Ministério Público - com aplicação de pena não privativa de liberdade -, o que levaria à não proposição de ação penal contra o suposto agressor.

Em termos concretos, ao desconsiderar a natureza e a complexidade dos conflitos envolvidos na violência doméstica, a Lei n. 9.099/95 acabou estimulando muitas mulheres ofendidas a desistirem de levar a conhecimento das autoridades as agressões sofridas. Havia uma constatação comum de que dificilmente o agressor iria de fato receber algum tipo de punição do Estado, fazendo a ofendida sentir-se desprotegida pela lei e até mais exposta a novas violências como "reprimenda" por ter ousado denunciar fatos que - na visão de muitos à época, e especialmente dos homens - deveriam ficar restritos ao ambiente doméstico.

Nesse cenário, a Lei Maria da Penha promoveu verdadeira revolução. Foram poucas as efetivas modificações trazidas à legislação penal, que se reduzem à

Consta no preâmbulo da Lei: "Cria mecanismos para coibir a violência doméstica e familiar contra a mulher, nos termos do $\S 8^{\circ}$ do art. 226 da Constituição Federal, da Convenção sobre a Eliminação de Todas as Formas de Discriminação contra as Mulheres e da Convenção Interamericana para Prevenir, Punir e Erradicar a Violência contra a Mulher; dispõe sobre a criação dos Juizados de Violência Doméstica e Familiar contra a Mulher; altera o Código de Processo Penal, o Código Penal e a Lei de Execução Penal; e dá outras providências". 
inclusão da violência doméstica na circunstância agravante prevista no art. 61, II, $f$, do CP, à nova redação dada à lesão corporal no âmbito da violência doméstica e ao aumento de sua pena cominada (art. 129, § $9^{\circ}$, do CP), e à imposição ao agressor de comparecimento obrigatório a programa de recuperação e reeducação como parte da pena de limitação de fim de semana (art. 152, § único, da LEP). Embora não tenha sido criado nenhum novo tipo penal incriminador, ${ }^{7}$ pela primeira vez no ordenamento jurídico brasileiro o legislador preocupou-se em conferir, de forma expressa, proteção às mulheres frente a agressões baseadas no gênero, e o fez discriminando as diferentes maneiras como a violência doméstica pode se apresentar. Foi feita referência a ações ou omissões que causem morte, lesão, sofrimento físico, sexual ou psicológico, assim como dano moral ou patrimonial, quando praticadas na unidade doméstica, no âmbito da família ou em qualquer relação íntima de afeto. ${ }^{8}$

Vê-se, assim, que a violência doméstica pode se apresentar sob diferentes infrações previstas na legislação penal, tais como homicídio, lesão corporal, estupro, ameaça, constrangimento ilegal, injúria, furto, apropriação indébita. Para o processamento desses fatos, foi prevista a criação dos Juizados de Violência Doméstica e Familiar contra a Mulher, órgão competente para lidar não só com os aspectos penais do conflito, mas também questões cíveis e de família; fora do plano jurídico, prevê-se também que às mulheres (e a seus filhos) seja dispensado atendimento e acolhimento social, médico e psicológico. A necessidade de se estruturar uma rede de proteção às mulheres, que se soma às respostas jurídicas, apresentou-se como forma bem mais eficiente para proteger a mulher que se encontra no complexo contexto conflituoso que é próprio da violência intrafamiliar.

No plano processual e da aplicação da pena, no entanto, algumas importantes modificações impostas pela Lei Maria da Penha impactaram significativamente na forma como se dá a proteção às mulheres na esfera criminal. Podem ser elencados, aqui, (a) a previsão expressa de não aplicação da Lei n. 9.099/95 aos crimes praticados no contexto da violência doméstica e familiar, independentemente da pena prevista, (b) a necessidade

Em 2018, com a Lei n. 13.641, foi inserido no art. 24-A da Lei Maria da Penha o tipo penal consistente em "descumprir decisão judicial que defere medidas protetivas de urgência previstas nesta lei".

8 Art. $5^{\circ}$ Para os efeitos desta Lei, configura violência doméstica e familiar contra a mulher qualquer ação ou omissão baseada no gênero que lhe cause morte, lesão, sofrimento físico, sexual ou psicológico e dano moral ou patrimonial: I - no âmbito da unidade doméstica, compreendida como o espaço de convívio permanente de pessoas, com ou sem vínculo familiar, inclusive as esporadicamente agregadas; II - no âmbito da família, compreendida como a comunidade formada por indivíduos que são ou se consideram aparentados, unidos por laços naturais, por afinidade ou por vontade expressa; III - em qualquer relação intima de afeto, na qual o agressor conviva ou tenha convivido com a ofendida, independentemente de coabitação. Parágrafo único. As relações pessoais enunciadas neste artigo independem de orientação sexual. 
de que a renúncia à representação, nos casos de ação penal pública condicionada, seja feita perante o juiz, em audiência específica, (c) a impossibilidade de imposição, ao agressor, de penas de pagamento de cesta básica ou de outras prestações pecuniárias, assim como a substituição de pena que implique o pagamento isolado de multa, (d) a previsão de medidas protetivas de urgência à mulher ofendida e a seus filhos, de modo a efetivamente protegê-los enquanto durar o processo, (e) a possibilidade de decretação de prisão preventiva para garantir a execução das medidas protetivas de urgência (art. 313 do CPP). Em decisão proferida em 2012 no âmbito da ADI n. 4.424/DF, o Supremo Tribunal Federal entendeu que a ação penal relativa à lesão corporal resultante de violência doméstica contra a mulher é pública incondicionada.

10.

O STF e a autorização do aborto de feto anencéfalo

Os tipos penais que preveem o crime de aborto (arts. 124, 125 e 126 do CP) não sofreram alteração desde 1940, quando o código penal brasileiro entrou em vigor; mantêm-se, portanto, as punições do aborto provocado pela própria gestante e, também, daquele praticado por terceira pessoa, com ou sem o consentimento dela. Da mesma forma, não foram objeto de alteração legislativa as hipóteses de não punição do crime descritas no art. 128 do CP, quais sejam, o aborto necessário (realizado como único meio para salvar a vida da gestante) e o aborto no caso de gravidez resultante de estupro.

Apesar de a lei penal não ter sido modificada, uma importante interpretação dada pelo Supremo Tribunal Federal sobre a matéria trouxe relevante impacto à sua aplicação. Trata-se da decisão proferida na ADPF n. 54/DF, na qual se entendeu que também não deve ser punida a interrupção da gravidez quando, por exames médicos absolutamente capazes de fazer o correto diagnóstico, o feto for anencéfalo. Significa dizer que, nesses casos, o fato de o embrião não ter "viabilidade de desenvolvimento e presença de características mentais de percepção, interação, emoção, relacionamento, consciência e intersubjetividade" torna a interrupção de seu desenvolvimento não punível pelo direito penal, da mesma forma que ocorre com as hipóteses legais descritas no art. 128 do CP.

Ao assim decidir, a Corte brasileira declarou a inconstitucionalidade da interpretação segundo a qual a interrupção da gravidez de feto anencéfalo é conduta tipificada nos arts. 124, 125, 126, 128, incisos I e II, do CP.

Trata-se, como se vê, de substanciosa alteração do alcance das normas penais que disciplinam o aborto, ainda que não tenha sido operada efetiva mudança no texto legal. Assim, em que pese o evidente avanço no que diz respeito aos direitos sexuais e reprodutivos da mulher, à sua autonomia, integridade física e psíquica, é forçoso constatar que, passada a segunda década do século 21 , a única alteração que se deu na 
matéria foi obra da jurisprudência, estando o direito positivo exatamente no mesmo lugar em que estava em $1940 .^{9}$

\section{A criação da figura do feminicídio}

Outra importante modificação pela qual passou a legislação brasileira no período analisado diz respeito à criação da figura do feminicídio no direito penal. Inserido pela Lei n. 13.104/15, o feminicídio não é propriamente um novo tipo incriminador, uma vez que a punição pela morte de mulheres sempre esteve abarcada no crime de homicídio; essa nova figura jurídica foi criada como circunstância qualificadora do crime de homicídio, onde se prevê que a pena é de reclusão de doze a trinta anos quando praticado contra mulher por razões da condição de sexo feminino (art. 121, $\S 2^{\circ}$, VI, CP), sendo que tal hipótese se verifica quando o crime envolve violência doméstica e familiar ou, ainda, menosprezo ou discriminação à condição de mulher (art. 121, § $2^{\circ} \mathrm{A}, \mathrm{CP}$ ).

A inserção desse elemento no direito penal brasileiro se dá num momento em que a América Latina se encontrava empenhada no combate à impunidade, evidenciado, especialmente, a partir de assassinatos de mulheres em Ciudad Juarez, no México, na década de 2000; naquele contexto, o Estado mexicano foi condenado pela Corte Interamericana de Direitos Humanos pela conivência com a violência misógina e a morte de mulheres (Caso González e outras ("Campo Algodoeiro”) vs. México), tendo sido levado a adotar a definição de "violência feminicida" em sua legislação nacional - o que serviu de modelo para a inserção do referido tipo penal em diversos outros países da região.

Além disso, e de maneira mais específica, pode-se dizer que se trata de consequência do movimento de criminalização da violência contra a mulher que teve na Lei Maria da Penha seu impulso inicial. Em junho de 2013 foi apresentado o Relatório Final da Comissão Parlamentar Mista de Inquérito criada "com a finalidade de investigar a situação da violência contra a mulher no Brasil e apurar denúncias de omissão por parte do poder público com relação à aplicação de instrumentos instituídos em lei para proteger as mulheres em situação de violência", no qual foi apresentado Projeto de Lei com vistas a inserir o feminicídio no direito brasileiro, em resposta ao constatado grande número de assassinatos de mulheres. ${ }^{10}$

9 Importante destacar que, embora represente visão minoritária no Brasil, o STF já manifestou entendimento no sentido de que a criminalização do aborto até o $3^{\circ}$ mês de gestação não condiz com os princípios da igualdade e da proporcionalidade, assim como contrasta com os direitos sexuais e reprodutivos da mulher, sua autonomia para fazer suas escolhas existenciais, e sua integridade física e psíquica afetada pela gravidez. Nesse sentido: STF, HC 124.306/RJ.

10 Nos termos do Relatório Final da CPMI: "É preciso dar um basta nas diversas manifestações de violência 
12. A Lei n. $13.718 / 18$ e as figuras da importunação sexual, estupros coletivo e corretivo, e divulgação de cena de estupro ou de sexo, nudez ou pornografia sem consentimento

No segundo semestre de 2018, nova mudança legislativa alterou o tratamento penal dado a crimes que, embora não tenham como sujeitos passivos necessariamente mulheres, estas costumam ser as pessoas que mais frequentemente são vítimas das condutas ali descritas.

Em resposta a uma série de atos libidinosos praticados contra mulheres em transporte público, mas que não se amoldavam à descrição típica do estupro por não haver violência ou ameaça à pessoa, foi criado o crime de importunação sexual, inserido no art. 215-A do código penal. Essa nova figura tinha como objetivo, portanto, não deixar impunes condutas como a ocorrida dentro de um ônibus na cidade de São Paulo, em que um homem ejaculou no pescoço de uma mulher e causou grande comoção e repercussão midiática. ${ }^{11}$

O novo tipo incriminador prevê pena de reclusão de 1 a 5 anos (se o ato não constitui crime mais grave) para quem praticar contra alguém e sem a sua anuência ato libidinoso com o objetivo de satisfazer a própria lascívia ou a de terceiro.

Outra figura criminosa inserida no ordenamento penal em 2018 foi a constante no novo art. 218-C do código penal, sob a rubrica "Divulgação de cena de estupro ou de cena de estupro de vulnerável, de cena de sexo ou de pornografia", e que corresponde a uma série de comportamentos voltados a expor a imagem da vítima.

Assim, passou-se a punir com reclusão de 1 a 5 anos a divulgação (por fotografia, vídeo ou outro registro audiovisual) de cena de estupro ou estupro de vulnerável, que faça apologia ou induza a sua prática, ou ainda cenas de sexo, nudez ou pornografia sem o consentimento da vítima. Diante do avanço tecnológico dos telefones celulares que possibilitou a quase todas as pessoas terem uma câmera sempre à mão, foi

contra as mulheres, sobretudo em sua forma extrema: o assassinato. Também urge lembrar que, no Brasil, os assassinatos de mulheres são praticados, majoritariamente, por parceiros íntimos. Nesse contexto, ganha especial destaque a chamada Lei Maria da Penha, diploma legal destinado ao enfrentamento da violência doméstica e familiar que este Colegiado busca aprimorar pontualmente, a fim de garantir-lhe a máxima eficácia.

"Importa considerar, ainda, no tocante ao feminicídio, a existência de recomendações internacionais para a sua tipificação, a exemplo daquelas inscritas no Relatório sobre Violência contra Mulheres, suas Causas e Consequências, assinado por Rashida Manjoo, assim como as Conclusões Acordadas da Comissão sobre o Status da Mulher, em sua 57 ${ }^{\text {a }}$ Sessão, em 15 de março de 2013. Esses e outros instrumentos internacionais estão a exigir uma resposta legislativa contra tal fenômeno, motivo por que leva este Colegiado a apresentar um projeto de lei tipificando o feminicídio".

11 https://g1.globo.com/sao-paulo/noticia/mulher-sofre-assedio-sexual-dentro-de-onibus-na-avenida-paulista. ghtml. Acesso em: 18 set. 2020. 
necessário que a legislação penal se adequasse à realidade para punir aqueles indivíduos que não se contentam mais com "apenas" estuprar mulher, mas que incrementam a ação delituosa registrando-a e divulgando-a; do mesmo modo, quem registra e divulga cenas de sexo, nudez ou pornografia sem o consentimento da outra pessoa, igualmente responde pelo crime.

O tipo penal prevê aumento de pena, ainda, para as hipóteses em que o agente mantém ou tenha mantido relação íntima de afeto com a vítima, ou se o crime é praticado com finalidade de vingança ou humilhação. Nesse aspecto, o legislador mostrou-se preocupado com um fenômeno cada vez mais presente entre as modalidades de violência de gênero contra as mulheres, que diz respeito à revenge porn, também conhecido no Brasil como "pornografia de vingança". Trata-se de comportamento em geral praticado por ex-maridos ou ex-namorados que, para expor suas ex-companheiras a constrangimento - muitas vezes devido à raiva ou mágoa pelo fim do relacionamento -, divulgam em redes sociais, grupos de mensagens ou sites na internet, imagens que fez da mulher enquanto estavam juntos.

Por fim, outras duas alterações que merecem ser citadas relacionam-se com o aumento de pena que passou a ser previsto para os crimes contra a dignidade sexual, e que se referem aos casos em que o crime é praticado por dois ou mais agentes e quando visa ao controle do comportamento social ou sexual da vítima. A primeira hipótese, denominada "estupro coletivo", responde à demanda social a partir de estupros praticados por diversos autores, em concurso de agentes, amplamente noticiados e causadores de grande comoção; já o segundo caso, denominado "estupro corretivo", tem um simbolismo importante no que diz respeito à violência de gênero pois evidencia uma preocupação em evitar que mulheres homossexuais sejam estupradas sob o pretexto de que precisam "corrigir" sua orientação sexual - algo claramente novo e muito mais coetâneo com a sociedade do século 21 do que, por exemplo, a figura da "mulher honesta" vigente até pouco tempo antes.

\section{Conclusões}

Embora possa haver uma distância entre os valores que orientam a elaboração do direito positivo e a forma como ele é interpretado quando posto em prática - e no caso do tema aqui estudado vislumbra-se um longo caminho até a formação de uma jurisprudência efetivamente voltada à proteção das mulheres frente a agressões relacionadas ao gênero -, não é possível desconsiderar os grandes avanços realizados nessa matéria, em boa parte devidos ao Poder Legislativo.

A comparação feita entre algumas das normas que estavam em vigor em 1998 e as que valiam em 2018 é muito significativa especialmente porque demonstra que, 
num campo em que as leis penais sempre foram demasiadamente influenciadas pela moral sexual, as mudanças operadas nesse lapso temporal apontam para uma grande revolução ocorrida na expectativa quanto à forma como os gêneros devem relacionar-se e, mais especificamente, na proteção que a mulher merece frente às diversas ofensas às quais sempre esteve e continua sendo exposta.

Embora as mudanças descritas não possam ser desvinculadas do empenho de grupos organizados de mulheres para fazer cessar as desigualdades e discriminações, o que não é recente e conta com uma importante história construída ao longo de décadas, também não deve ser desconsiderado o fato de alterações tão significativas terem se dado em apenas 20 anos, com impacto na própria lógica estruturante do ordenamento jurídico.

Não é pouca coisa, nesse curto período, o direito penal ter deixado de ter como norte a proteção da moral sexual das famílias para voltar-se à tutela da dignidade feminina frente a abusos sexuais, tendo como consequência, por exemplo, o abandono da concepção da mulher como alguém inexperiente e incapaz de resistir aos encantos do varão galanteador - o que justificava ser tutelada em caso de sedução - para considerála alguém que, inserida no mercado de trabalho e responsável pelo sustento familiar, precisa ter proteção legal para não ser assediada sexualmente sob a ameaça de perder seu emprego. Da mesma forma, o casamento deixou de ser visto como o único modo de realização da mulher - a ponto de eliminar a punição de crimes sexuais se tais ofensas não a impedissem de casar ou mesmo diminuir a pena do rapto se ela fosse restituída integralmente à sua família - e todas as formas de realização sexual da mulher passaram a ser tuteladas, inclusive tornando o estupro corretivo digno de reprimenda maior. Da mesma forma, se o ordenamento se livrou de concepções ultrapassadas, como a ideia de "mulher honesta", a previsão de punição da pornografia de vingança não só demonstra a atualização da proteção dispensada à mulher, mas também indica a necessidade de constante atenção frente às novas violências proporcionadas pelas novas tecnologias.

Nesse contexto, ao mesmo tempo em que deve ser reconhecido o avanço pelo qual a legislação penal brasileira passou nos últimos 20 anos, os desafios à proteção à mulher continuam extremamente atuais e merecedores de atenção. $\mathrm{O}$ maior cuidado dispensado à violência doméstica, a grande visibilidade que passaram a ter os casos de feminicídio, a divulgação de ofensas e material constrangedor pelas redes sociais, por exemplo, são apenas uma amostra do que se espera do ordenamento jurídico nos próximos anos.

São Paulo, 24 de setembro de 2020. 


\section{Referências}

BATISTA, Nilo. Introdução crítica ao direito penal brasileiro. 4. ed. Rio de Janeiro: Revan, 1999.

CHAKIAN, Silvia. A construção dos direitos das mulheres: histórico, limites e diretrizes para uma proteção penal eficiente. Rio de Janeiro: Lumen Juris, 2019.

DEL PRIORE, Mary. Histórias e conversas de mulher. São Paulo: Planeta, 2013.

DELMANTO, Celso; DELMANTO, Roberto; DELMANTO JÚNIOR, Roberto; DELMANTO, Fabio Machado de Almeida. Código penal comentado: acompanhado de comentários, jurisprudência, súmulas em matéria penal e legislação complementar. 5. ed. Rio de Janeiro: Renovar, 2000.

FLORA, Giovanni. Manuale per lo studio della parte speciale del diritto penale. Padova: CEDAM, 1998. v. 1: Il "sistema" della parte speciale.

FRANCO, Alberto Silva; SILVA, Tadeu Antonio Dix. Dos crimes contra os costumes. In: FRANCO, Alberto Silva; STOCO, Rui (coord.). Código penal e sua interpretação: doutrina e jurisprudência. 8. ed. São Paulo: Revista dos Tribunais, 2007.

GOMES, Mariângela Gama de Magalhães. Teoria geral da parte especial do direito penal. São Paulo: Atlas, 2014.

HESPANHA, António Manuel. Carne de uma só carne: para uma compreensão dos fundamentos histórico-antropológicos da família na época moderna. Análise Social, Lisboa, v. 28, n. 123-124, p. 951-973, 1993.

HUNGRIA, Nélson; LACERDA, Romão Côrtes de. Comentários ao código penal. 4. ed. Rio de Janeiro: Forense, 1959. v. 8: arts. 197 a 249.

JESUS, Damásio Evangelista de. Direito penal. São Paulo: Saraiva, 1999. v. 2.

MANTOVANI, Ferrando. Il principio di offensività nello schema di delega legislativa per un nuovo codice penale. Rivista Italiana di Diritto e Procedura Penale, Milano, v. 40, n. 2, p. 313-337, apr./ giugo 1997.

MIRABETE, Júlio Fabbrini. Manual de direito penal. 10. ed. São Paulo: Atlas, 1996. v. 2.

MONTENEGRO, Marilia. Lei Maria da Penha: uma análise criminológico-crítica. Rio de Janeiro: Revan, 2015.

MULHER sofre assédio sexual dentro de ônibus na Avenida Paulista. G1, São Paulo, 29 ago. 2017. Disponível em: https:/g1.globo.com/sao-paulo/noticia/mulher-sofre-assedio-sexual-dentro-deonibus-na-avenida-paulista.ghtml. Acesso em: 18 set. 2020.

NORONHA, Edgard Magalhães. Direito penal. 4. ed. São Paulo: Saraiva, 1969. v. 3.

NUCCI, Guilherme de Souza. Código penal comentado. 3. ed. São Paulo: Revista dos Tribunais, 2003 . 
PRADO, Luiz Regis. Bem jurídico-penal e constituição. São Paulo: Revista dos Tribunais, 1996.

SILVA, Tadeu Antônio Dix. Crimes sexuais: reflexões sobre a nova Lei 11.106/2005. Leme: J. H. Mizuno, 2006.

SILVEIRA, Renato de Mello Jorge. Dos crimes contra a dignidade sexual. In: REALE JÚNIOR, Miguel (org.). Código penal comentado. São Paulo: Saraiva, 2017. p. 642-680. 
